\title{
Discovery and Engineering of an Aldehyde Tolerant 2-deoxy-D-ribose 5-phosphate Aldolase (DERA) from Pectobacterium atrosepticum
}

\author{
Meera Haridas ${ }^{1,+}$, Carolin Bisterfeld ${ }^{1, \dagger}{ }^{+}$Le Min Chen ${ }^{1}$, Stefan R. Marsden ${ }^{1}$, Fabio Tonin ${ }^{1}$, \\ Rosario Médici $^{1}$, Adolfo Iribarren ${ }^{2}$, Elizabeth Lewkowicz ${ }^{2} \mathbb{D}$, Peter-Leon Hagedoorn ${ }^{1}{ }^{\mathbb{D}}$, \\ Ulf Hanefeld 1,*(D) and Eman Abdelraheem 1,*(D) \\ 1 Department of Biotechnology, Delft University of Technology, Van der Maasweg 9, 2629 HZ Delft, \\ The Netherlands; Meera.hds@gmail.com (M.H.); carolin.bisterfeld@hhu.de (C.B.); \\ l.m.chen@student.tudelft.nl (L.M.C.); S.R.Marsden@tudelft.nl (S.R.M.); f.tonin@tudelft.nl (F.T.); \\ romedici@gmail.com (R.M.); p.l.hagedoorn@tudelft.nl (P.-L.H.) \\ 2 Laboratorio de Biotransformaciones, Department of Science and Technology, CONICET, \\ Universidad Nacional de Quilmes, Roque S. Peña 352, Bernal Este B1876BXD, Argentina; \\ airibarren@unq.edu.ar (A.I.); elewko@unq.edu.ar (E.L.) \\ * Correspondence: u.hanefeld@tudelft.nl (U.H.); e.m.m.abdelraheem@tudelft.nl (E.A.); \\ Tel.: +31-15-2789304 (U.H.) \\ + These authors contribute equally in this work.
}

Received: 15 July 2020; Accepted: 3 August 2020; Published: 5 August 2020

\begin{abstract}
DERA (2-Deoxy-D-ribose 5-phosphate aldolase) is the only known aldolase that accepts two aldehyde substrates, which makes it an attractive catalyst for the synthesis of a chiral polyol motif that is present in several pharmaceuticals, such as atorvastatin and pravastatin. However, inactivation of the enzyme in the presence of aldehydes hinders its practical application. Whole cells of Pectobacterium atrosepticum were reported to exhibit good tolerance toward acetaldehyde and to afford 2-deoxyribose 5-phosphate with good yields. The DERA gene ( $P a$ DERA) was identified, and both the wild-type and a C49M mutant were heterologously expressed in Escherichia coli. The purification protocol was optimized and an initial biochemical characterization was conducted. Unlike other DERAs, which show a maximal activity between $\mathrm{pH} 4.0$ and 7.5, PaDERA presented an optimum $\mathrm{pH}$ in the alkaline range between 8.0 and 9.0. This could warrant its use for specific syntheses in the future. PaDERA also displayed fourfold higher specific activity than DERA from E. coli (EcDERA) and displayed a promising acetaldehyde resistance outside the whole-cell environment. The C49M mutation, which was previously identified to increase acetaldehyde tolerance in EcDERA, also led to significant improvements in the acetaldehyde tolerance of PaDERA.
\end{abstract}

Keywords: DERA; Pectobacterium atrosepticum; aldolase; acetaldehyde resistance

\section{Introduction}

Aldolases are a class of enzymes that catalyze aldol reactions between two carbonyl compounds. DERA (2-Deoxy-D-ribose 5-phosphate aldolase) occupies an important position in biological systems, since it is involved in the catabolism of nucleosides. Pentose phosphates (specifically ribose 5-phosphate (R5P) and 2-deoxyribose 5-phosphate $\left(\mathrm{DR}_{5} \mathrm{P}\right)$ ) are the building blocks of nucleosides and in turn also of ribonucleotides and deoxy ribonucleotides [1]. In 1951, Racker reported that cellular extracts of E. scherichia coli catalyze the reversible reaction of glyceraldehyde 3-phosphate (GAP) with acetaldehyde to give DR5P [2]. DERA has since been utilized as a biocatalyst for the synthesis of epothilones, which are inhibitors of microtubule function and as such show potential as anticancer drugs [3]. DERA has 
also been utilized for the synthesis of different types of deoxysugars, such as deoxy-, dideoxy-, trideoxy-, aza- and thio sugars [4]. Additionally, DERA has provided a straightforward route toward pyrimidine nucleosides [5,6], 5-deoxy ketoses and nine carbon sialic acid-type sugar derivatives $[7,8]$. Most intriguingly, DERA can also catalyze sequential aldol reactions (Scheme 1) [9]. The sequential conversion of two acetaldehyde molecules is one of the most promising methods for the synthesis of statin side chains, creating both stereocenters in a single step [10-14]. Statins are drugs frequently prescribed to reduce LDL cholesterol blood levels by inhibiting the 3-hydroxy-3-methyl-glutaryl-CoA reductase. The recent application of DERA for the synthesis of islatravir demonstrates its potential in industry [15].

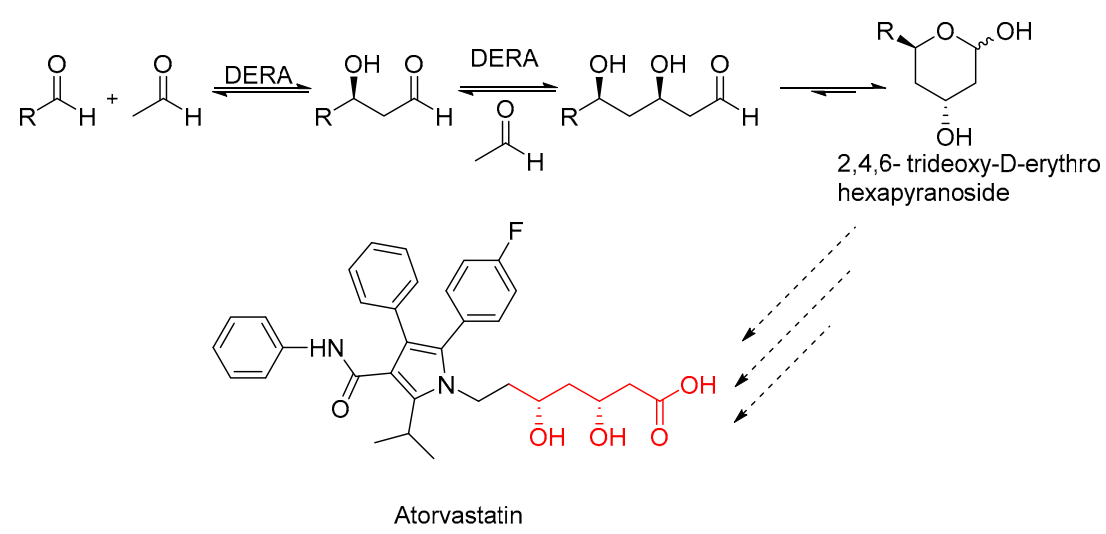

Scheme 1. PaDERA C49M catalyzed sequential aldol reaction between three acetaldehyde molecules.

Yet, industrial scale applications of DERA have so far been limited due to its poor stability toward high concentrations of acetaldehyde and its derivatives. In addition, the catalytic efficiency for sequential aldol reactions with unnatural substrates is low. Valino et al. carried out a hierarchical screening of different bacteria to identify strains, which show DERA activity. In particular, Pectobacterium atrosepticum (formerly Erwinia caratovora) ATCC 33260, a Gram-negative phytopathogenic bacterium, was reported to efficiently synthesize DR5P from GAP and acetaldehyde in whole-cell bioconversions [5]. Here, we report the heterologous expression and characterization of PaDERA and a C49M single mutant, which shows improved acetaldehyde tolerance. The properties of these variants were biochemically characterized and compared with E. coli DERA (EcDERA).

\section{Results}

\subsection{Identification of PaDERA}

The deoC gene was amplified from the bacterial genome of $P$. atrosepticum and cloned into the pET-28a expression vector containing either an $\mathrm{N}$ - or $\mathrm{C}$-terminal $\mathrm{His}_{6}$-tag. PaDERA was then heterologously expressed in E. coli BL21(DE3) and purified by affinity chromatography using EcDERA as reference.

$\mathrm{PaDERA}-\mathrm{C}-\mathrm{His}_{6}$ contained two extra amino acids at the $\mathrm{N}$-terminus and three extra amino acids as a spacer between the enzyme and the $\mathrm{His}_{6}$-tag. In order to exclude any negative effects on the activity of $\mathrm{PaDERA}$, the $\mathrm{C}$-terminally $\mathrm{His}_{6}$-tagged protein was also produced without this small spacer (see Table S1). Pure DERAs were obtained by affinity chromatography according to SDS-PAGE analyses (Figure S5). The initial purification protocol involved a gradient elution (elution buffer: $1 \mathrm{M}$ imidazole, pH 7 and running buffer: $100 \mathrm{mM} \mathrm{KPi}, \mathrm{pH} 7$ ), but several other proteins were obtained alongside our protein of interest (AC and AD lanes, Figure S5A). Consequently, the gradient elution step was replaced by several longer, isocratic elution steps with the same elution buffer and running buffer. After stepwise washing with $3 \mathrm{~mL}$ fractions of running buffer containing 0, 25, 50, $100 \mathrm{mM}$ imidazole, enzyme was eluted from the column using fractions $3 \mathrm{~mL}$ purification buffer containing $250 \mathrm{mM}$ 
and $2 \times 500 \mathrm{mM}$ imidazole. This optimized elution protocol is shown in Figure S5B and SDS-PAGE analyses indicated an improved purification in the form of a sharp band for PaDERA.

The activity of $P a D E R A$ with the small spacer was found to be slightly higher than that of $P a D E R A$ without the spacer, namely $13.7 \mathrm{U} / \mathrm{mg}$ and $13.0 \mathrm{U} / \mathrm{mg}$, respectively. Therefore, from here on only PaDERA-C-His 6 , which includes the small spacer, is discussed. The data obtained using the enzyme without the spacer can be found in Table S2. PaDERA was found to be fourfold more active than EcDERA (3.5 U/mg). This demonstrates that PaDERA is a promising new member of the DERA toolbox.

\subsection{Characterization of PaDERA}

The activity and stability of purified PaDERA was investigated using a coupled enzymatic assay with DR5P as substrate. The kinetic behavior of PaDERA toward DR5P can be described by the Michaelis-Menten kinetic parameters. PaDERA and EcDERA activity was measured over a range from 0 to $2 \mathrm{mM}$ of DR5P and fitted using the Michaelis-Menten equation (Figure S3). The $V_{\max }$ of PaDERA $(17.67 \pm 1.01 \mathrm{U} / \mathrm{mg})$ for DR5P cleavage was found to be higher than that of $E c$ DERA $(4.21 \pm 0.21 \mathrm{U} / \mathrm{mg})$ under the same conditions, while the catalytic efficiencies are comparable $\left(39.1 \pm 9.4 \mathrm{mM}^{-1} \mathrm{~s}^{-1}\right.$ for PaDERA and $31.25 \pm 11.7 \mathrm{mM}^{-1} \mathrm{~s}^{-1}$ for EcDERA, Table 1).

Table 1. Michaelis-Menten kinetic parameters of PaDERA and EcDERA *.

\begin{tabular}{cccccc}
\hline Enzyme & $\mathbf{M W}^{\mathbf{a}} \mathbf{( k D a )}$ & $\boldsymbol{K}_{\boldsymbol{M}}(\mathbf{m M})$ & $\boldsymbol{V}_{\max }(\mathbf{U} / \mathbf{m g})$ & $\boldsymbol{k}_{\text {cat }}\left(\mathbf{s}^{\mathbf{- 1}}\right)$ & $\boldsymbol{k}_{\text {cat }} / \boldsymbol{K}_{\boldsymbol{M}}\left(\mathbf{m M}^{-\mathbf{1}} \mathbf{s}^{-\mathbf{1}}\right)$ \\
\hline$P a D E R A$ & 28.858 & $0.22 \pm 0.04$ & $17.67 \pm 1.01$ & $8.50 \pm 0.48$ & $39.1 \pm 9.4$ \\
$E c D E R A$ & 28.556 & $0.06 \pm 0.02$ & $4.21 \pm 0.21$ & $2.00 \pm 0.10$ & $31.25 \pm 11.7$ \\
\hline
\end{tabular}

a calculated from the amino-acid sequence, ${ }^{*}$ the standard reaction mixture contained 0-2 mM DR5P, $0.2 \mathrm{mM} \mathrm{NADH}$,

$3 \mathrm{U}$ GDH, $11 \mathrm{U}$ TPI and $10 \mu \mathrm{L}$ DERA. The volume was made up to $1 \mathrm{~mL}$ with $100 \mathrm{mM}$ TEA buffer, $\mathrm{pH} 7,25^{\circ} \mathrm{C}$.

Subsequently, the thermostability of the different DERA enzymes was investigated. At $40{ }^{\circ} \mathrm{C}$, PaDERA retained up to $90 \%$ of its initial activity after $10 \mathrm{~min}$ of incubation, and $80 \%$ after $60 \mathrm{~min}$, respectively (Figure 1). However, only $60 \%$ of its initial activity was retained after incubation at $50{ }^{\circ} \mathrm{C}$ for $10 \mathrm{~min}$. Since P. atrosepticum is a mesophilic bacterium we assume that the loss of the activity above $60{ }^{\circ} \mathrm{C}$ as shown in Figure 1 is due to the protein denaturation. Notably, this behavior is similar to that of $H$. influenza DERA. On the other hand, EcDERA fully retains its initial activity after incubation at $60{ }^{\circ} \mathrm{C}$ for $60 \mathrm{~min}$.

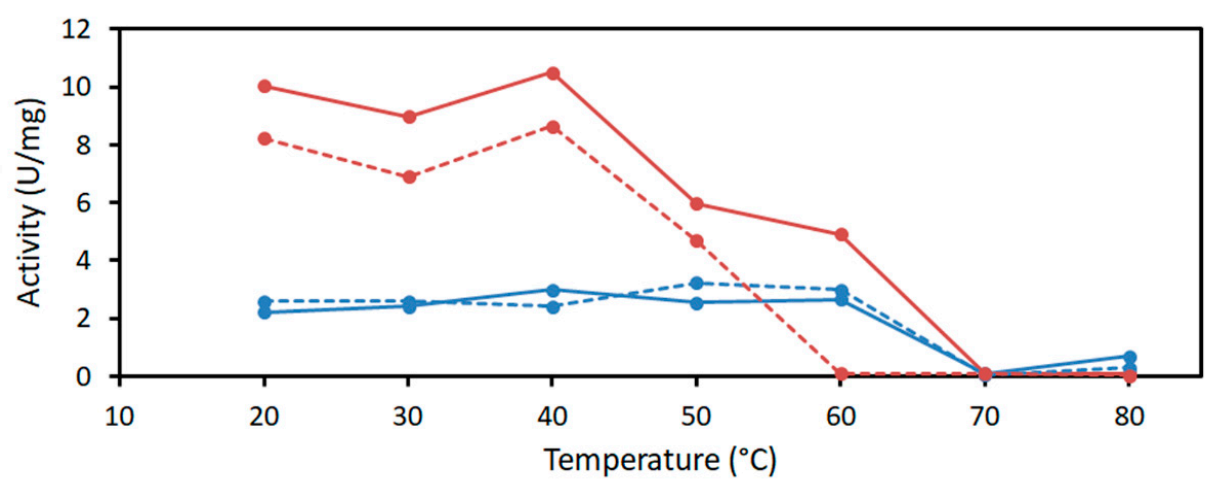

Figure 1. Overview of residual activity after incubation of $P a D E R A$ (red) and EcDERA (blue) at different temperatures $\left(20-80{ }^{\circ} \mathrm{C}\right)$ in TEA buffer $(100 \mathrm{mM}$, pH 7.0) measured after $10 \mathrm{~min}$ (continuous lines) and $60 \mathrm{~min}$ (dotted lines) of incubation. The activity was measured using the standard assay procedure at $25^{\circ} \mathrm{C}$.

$\mathrm{Pa}$ DERA showed high activities at alkaline $\mathrm{pH}$ in glycine- $\mathrm{NaOH}$ or triethanolamine (TEA)buffer. The activity of $P a$ DERA was optimal between $\mathrm{pH} 8.0$ and 9.0. EcDERA showed a maximal activity in range $\mathrm{pH} 7.0-9.0$ as shown in Figure 2. 

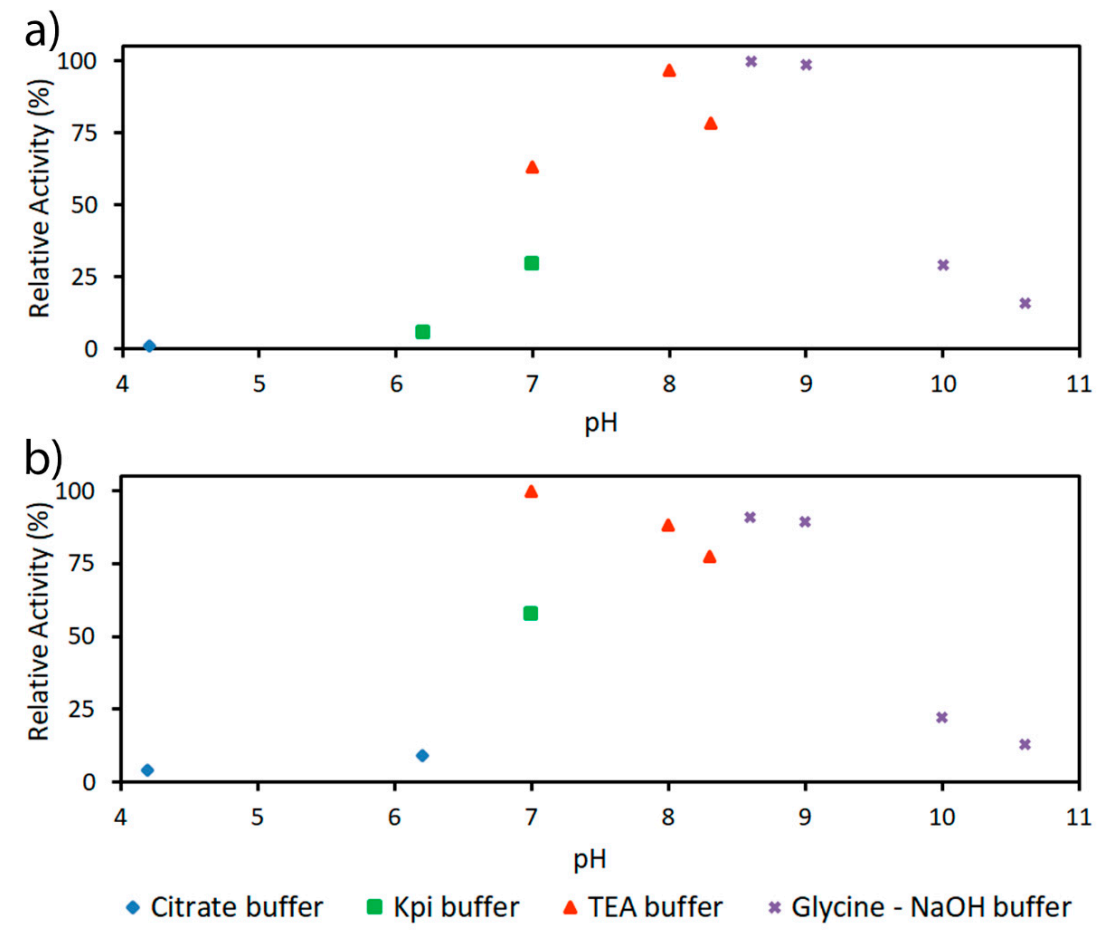

Figure 2. Overview of relative activity of (a) PaDERA and (b) EcDERA at different pH values. The enzyme assay was performed using the standard assay procedure in the following buffers $(100 \mathrm{mM})$ : (1) Citrate ( $\mathrm{pH} 4.2,5.0$ and 6.2), (2) KPi (pH 6.2, 7.0 and 8.2), (3) TEA (pH 7.0, 8.0 and 8.3) and (4) Glycine- $\mathrm{NaOH}(\mathrm{pH} 8.6,9.0,10.0$ and 10.6).

\subsection{Acetaldehyde Tolerance of DERA Enzymes}

A direct comparison of the acetaldehyde resistance of EcDERA with PaDERA was performed. An exponential decay of DERA activity was observed for both EcDERA and PaDERA in the presence of $100 \mathrm{mM}$ of acetaldehyde (Figure 3). Interestingly, PaDERA appears to be more tolerant toward high concentrations of acetaldehyde than EcDERA, retaining 30\% of its initial activity after 40 min of incubation. Under the same conditions, EcDERA is completely inactivated after only $20 \mathrm{~min}$ [16].

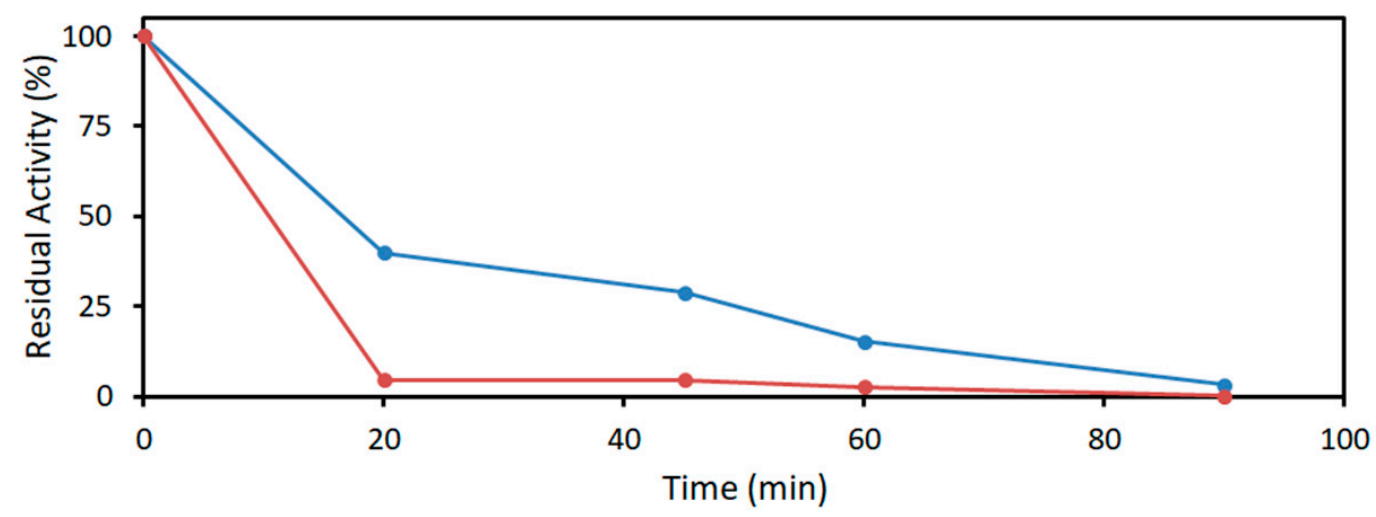

Figure 3. DERA inactivation of the two variants PaDERA (blue) and EcDERA (red) upon incubation with $100 \mathrm{mM}$ acetaldehyde at $25^{\circ} \mathrm{C}$ in $100 \mathrm{mM}$ TEA buffer $\mathrm{pH}$ 7.0. A specific activity of $11.9 \mathrm{U} / \mathrm{mg}$ for PaDERA and $1.7 \mathrm{U} / \mathrm{mg}$ for EcDERA were normalized at $100 \%$.

For EcDERA, the C47M mutation was reported to significantly improve acetaldehyde resistance, as it replaces a cysteine, that has been proposed to be involved in the deactivation mechanism [16]. EcDERA Cys47 is conserved in PaDERA and corresponds to Cys49. Moreover, the two sequences share 
considerable identity around the Cys47/Cys49 position, as can be seen from the alignment in Figure S1. Therefore, the effect of the mutation C47M on PaDERA was investigated. The PaDERA C49M variant was expressed and purified following the same, approach as for the WT enzyme (Figures S4 and S5). The acetaldehyde resistance of the C49M mutant was evaluated by incubating the enzyme in the presence of $100 \mathrm{mM}, 200 \mathrm{mM}$ and $300 \mathrm{mM}$ of acetaldehyde and measuring the residual activity at various time points using the coupled assay under standard conditions. In comparison to the wild-type enzyme, PaDERA C49M showed excellent stability in the presence of up to $300 \mathrm{mM}$ of acetaldehyde, where it retained $90 \%$ of its activity after incubation for $90 \mathrm{~min}$ (Figure 4 ). In contrast, wild-type $\mathrm{PaDERA}$ lost $70 \%$ of its activity after incubation for $30 \mathrm{~min}$ in the presence of $100 \mathrm{mM}$ acetaldehyde.

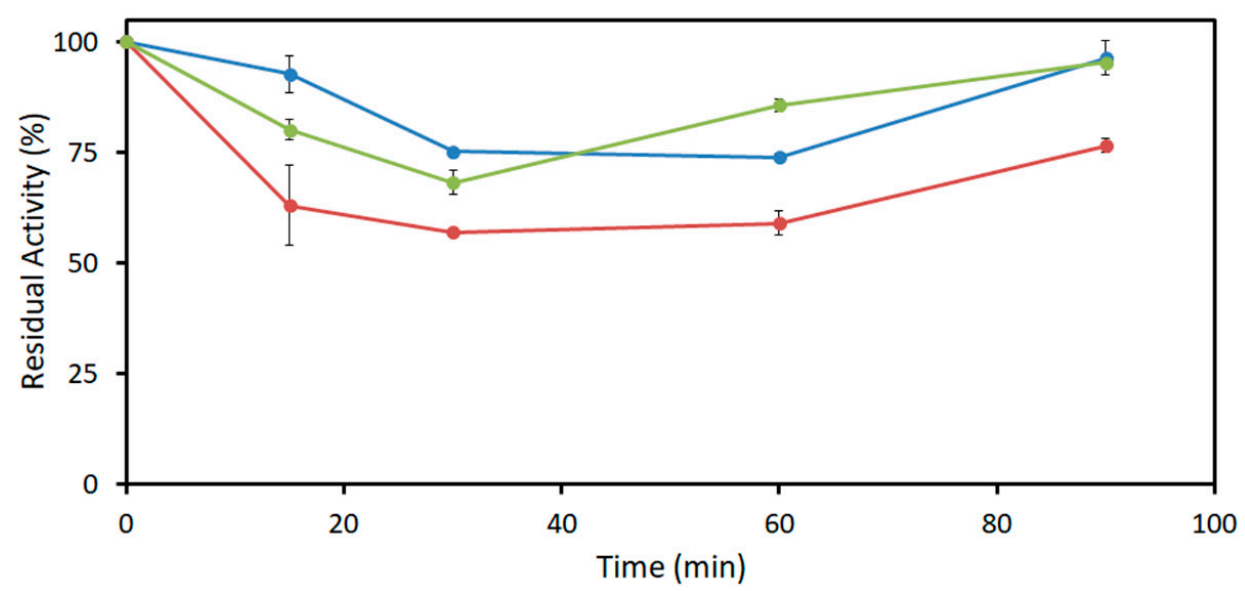

Figure 4. Time-dependent activity of PaDERA C49M during incubation at different acetaldehyde concentrations (100 mM (blue), $200 \mathrm{mM}$ (red) and $300 \mathrm{mM}$ (green)) to estimate the residual activity using the standard assay protocol. The residual activity after incubation in the absence of acetaldehyde was $3.5 \mathrm{U} / \mathrm{mg}$ and was normalized to $100 \%$.

Finally, the PaDERA C49M variant was employed in the sequential aldol reaction for the enzymatic synthesis of 2,4,6-trideoxy-D-erythrohexapyranoside (Scheme 1). Whole cells of E. coli ( $3 \mathrm{mg} / \mathrm{mL}$ ) containing the PaDERA C49M variant were incubated with $100 \mathrm{mM}$ of acetaldehyde for $48 \mathrm{~h}$. The product was directly extracted from the reaction mixture and the yield of $50 \%$ was obtained without further purification. The product was confirmed by gas chromatography(GC), ${ }^{1} \mathrm{H}-\mathrm{NMR}$ and ${ }^{13}$ C-NMR spectroscopy (Figures S6 and S7) [17].

\section{Discussion}

One of the bottlenecks in the enzymatic synthesis of polyol motif synthons is represented by the poor stability of DERAs in acetaldehyde. For this reason, it is necessary to evaluate the synthetic performances of new DERA enzymes from different organisms. Here, the properties of DERA from P. atrosepticum (PaDERA) were investigated.

Recombinant expression of PaDERA was successfully demonstrated in E. coli and the enzyme was purified in a single chromatographic step. In order to allow direct comparison, the well-known enzyme from E. coli (EcDERA) was locally produced and purified as well.

PaDERA showed biochemical properties that are comparable to those of other members of the DERA family. While PaDERA is stable at up to $40{ }^{\circ} \mathrm{C}$, DERAs with a higher thermostability have been reported, e.g., DERAs from several strains including Paenibacillus sp. EA001, Haloarcula japonica and Aciduliprofundum boonei were shown to be highly stable after incubation at 50, 60 and $80{ }^{\circ} \mathrm{C}$, respectively.

PaDERA has an optimum $\mathrm{pH}$ in the basic range from 8.0 and 9.0, which is similar to DERAs from E. coli and Salmonella typhimurium. DERAs from Thermococcus kodakaraensis, Lactobacillus brevis and Rhodococcus erythropolis have been reported to have an optimum activity in acidic range 4.0 to 6.0 (Table S2). At pH 7 the activity in phosphate buffer was lower than in TEA buffer. Apparently 
there is a buffer effect of either phosphate buffer or TEA buffer on DERA or the enzyme used in the coupled assay. We did not observe an effect of phosphate addition in independent enzyme assays with PaDERA. To our knowledge no negative or positive effects of these buffer components on DERA have been reported previously. In our hands, the $V_{\max }$ of $P a$ DERA was circa fourfold higher than that of EcDERA under identical assay conditions. However, previously reported kinetic parameters for $E c$ DERA (Table S2) are significantly higher than the values that were obtained here, with a $K_{M}$ of 0.23-0.29 $\mathrm{mM}$ for DR5P and $V_{\max }$ of 58-85 $\mathrm{U} / \mathrm{mg}$, despite using highly similar assay conditions $[18,19]$. We do not have an explanation for the observed differences.

The tolerance of aldolases toward aldehyde substrates is important for the enzyme function and reaction efficiency. In this study, we showed that wild-type PaDERA is more stable than wild-type EcDERA in the presence of $100 \mathrm{mM}$ of acetaldehyde. The C49M mutation further improved the aldehyde tolerance of $P a$ DERA. Surprisingly, its residual activity increased again after incubation for $60 \mathrm{~min}$ at $100 \mathrm{mM}, 200 \mathrm{mM}$ and $300 \mathrm{mM}$ of acetaldehyde. This may be due to an increased carry-over of acetaldehyde to the enzyme assay mixture, which may affect the result of the coupled assay. EcDERA C47M showed no loss of activity after incubation in $300 \mathrm{mM}$ of acetaldehyde for $16 \mathrm{~h}$. For EcDERA, it has been reported that the product of the DERA catalyzed aldol reaction of acetaldehyde can undergo water elimination resulting in crotonaldehyde. Cysteine 47 reacts with the crotonaldehyde via a Michael addition, deactivating the enzyme. By replacing cysteine 47 with methionine this deactivation mechanism is suppressed [16].

Furthermore, the aldehyde tolerance of PaDERA C49M is similar to that of T120C, G174I and G213C mutants of Staphylococcus epidermidis DERA, which was determined to be $70.5 \%$ under similar conditions (see Table S2) [20]. In contrast, wild-type EcDERA was reported to be almost completely inactivated after incubation in $300 \mathrm{mM}$ acetaldehyde for $3 \mathrm{~h}[16,18]$.

\section{Materials and Methods}

\subsection{Chemicals}

Each of 2-Deoxy-D-ribose 5-phosphate, DL-glyceraldehyde-3-phosphate and acetaldehyde were obtained from Sigma-Aldrich (Saint Louis, MS, USA). Acetaldehyde was of the highest analytical purity and it was purchased in small vials of $5 \mathrm{~mL}$. Deionized water was used for all experiments. $\alpha$-Glycerophosphate Dehydrogenase-Triose phosphate Isomerase (GDH-TPI) was obtained from Sigma-Aldrich. T4 DNA ligase and DpnI were obtained from Biolabs. Phusion HS-II MM high-fidelity polymerase was obtained from Thermo Fischer Scientific.

\subsection{Molecular Biology Methods}

\subsubsection{Cloning of DeoC P. atrosepticum}

The deoC gene from P. atrosepticum ATCC 33.260 (Figure S1) encoding PaDERA (NCBI Reference Sequence: WP_039289985) was cloned from the bacterial genome Erwinia carotovora into the expression vector pET-28 a (+) carrying the resistance to kanamycin. The deoC gene was amplified by polymerase chain reaction (PCR) in frame with $\mathrm{N}$-terminal or C-terminal His-tag. The primers for the PCR contain a NcoI and XhoI site at the N- and C-terminus and are showed in Table S1. A PCR was done with the Phusion HS-II MM high-fidelity polymerase and a gel purification of the PCR product was performed to obtain pure $d e o \mathrm{C}_{\mathrm{Pa}}$ DNA. The sequences of the obtained plasmids were analyzed by BaseClear (Leiden, The Netherlands).

\subsubsection{Site-Directed Mutagenesis of $P a D E R A$}

Mutant C49M was prepared using the QuikChange site-directed mutagenesis kit(Agilent Technologies, California, USA). A total reaction volume of $20 \mu \mathrm{L}$ was used, containing approximately $5 \mathrm{ng}$ template of deoxyribonucleic acid (DNA), $10 \mu \mathrm{L}$ of DNA polymerase and reverse and forward 
mutagenic primers $10 \mu \mathrm{M}$ (each). The mutagenic primers are listed in Table S1. Gradient PCR program included $95{ }^{\circ} \mathrm{C}$ for $30 \mathrm{~s} ; 32$ cycles of $95^{\circ} \mathrm{C} 30 \mathrm{~s}, 64-74{ }^{\circ} \mathrm{C} 30 \mathrm{~s}$ and $72{ }^{\circ} \mathrm{C} 2 \mathrm{~min} ; 72{ }^{\circ} \mathrm{C}$ for $10 \mathrm{~min}$. Ligation was carried out after PCR, $2 \mu \mathrm{L}$ 10x T4 DNA ligase buffer and $1 \mu \mathrm{L}$ T4 DNA ligase were added to the PCR product and incubated at room temperature for $1 \mathrm{~h}$. DpnI digestion was carried out to selectively digest the naturally methylated DNA template: $2 \mu \mathrm{L}$ 10x NEB-buffer and $1 \mu \mathrm{L}$ DpnI enzyme were added to the ligated PCR product and incubated for $4 \mathrm{~h}$ at $37^{\circ} \mathrm{C}$ (Innova Incubator, Hamburg, Germany). Afterwards, the PCR product was transformed into E. coli TOP10 and grown in $5 \mathrm{~mL}$ LB-kan for $16 \mathrm{~h}$ at $37^{\circ} \mathrm{C}$. DNA plasmid was isolated using the mini prep kit (Qiagen, Hilden, Germany) from three isolated colonies and further quantified using a Nanodrop spectrophotometer (Thermo Fischer Scientific, Waltham, USA). Correct introduction of the mutation was confirmed by sequencing at BaseClear (Leiden, The Netherlands).

\subsubsection{Protein Expression and Purification}

Chemically competent E. coli BL21 (DE3) was transformed with the different plasmids according to the heat shock method. These transformants $(10-100 \mu \mathrm{L})$ were plated on LB-agar containing $30 \mu \mathrm{g} / \mathrm{mL}$ kanamycin and incubated at $37^{\circ} \mathrm{C}$ overnight. The preculture was prepared by picking individual colonies to inoculate a $10 \mathrm{~mL} \mathrm{LB}$ medium containing $10 \mu \mathrm{g} / \mathrm{mL}$ kanamycin (kan) grown at $37^{\circ} \mathrm{C}, 180 \mathrm{rpm}$ overnight. The preculture was used to inoculate $1 \mathrm{~L} \mathrm{LB}$ medium containing $10 \mu \mathrm{g} / \mathrm{mL}$ kanamycin. Protein expression was induced at OD600 $=0.8-1.0$ by the addition of isopropyl- $\beta$-d-thiogalactoside (IPTG) to a final concentration of $0.1 \mathrm{mM}$ and cultures were grown overnight at $25^{\circ} \mathrm{C}, 120 \mathrm{rpm}$. Cells were harvested by centrifugation at $4{ }^{\circ} \mathrm{C}, 8000 \mathrm{rpm}$ for $15 \mathrm{~min}$ and were stored at $-20^{\circ} \mathrm{C}$.

Cells were resuspended in buffer A (100 mM KPi, $0.5 \mathrm{mM} \mathrm{NaCl}, \mathrm{pH} 7.0)$ to achieve an end concentration of $20 \% \mathrm{w} / \mathrm{v}$. The resuspended cells were then disrupted on ice using Branson Sonifier 250 (Emerson Electric, St. Louis, USA) at a power output of 2 and $40 \%$ duty cycle for $15 \mathrm{~min}$. The disrupted cells were centrifuged at $4{ }^{\circ} \mathrm{C}$ and $4000 \mathrm{rpm}$ for $15 \mathrm{~min}$ and the cell free extract was obtained as the supernatant. A His-trap FF $1 \mathrm{~mL}$ column containing $\mathrm{Ni}^{2+}$-NTA (Nickel-Nitrilotriacetic acid) (GE, Healthcare, New York, N.Y., USA) was used for all purifications. The column was first equilibrated with 3-5 column volumes of buffer A. It was then loaded with the cell free extract. The protein of interest was eluted from the column using buffer B (100 mM KPi, $1 \mathrm{M}$ Imidazole, $0.5 \mathrm{M} \mathrm{NaCl}, \mathrm{pH} 7.0)$ in isocratic steps until the desired protein eluted at $50 \%$ buffer $\mathrm{B}$. The purification was carried out on the NGC Chromatography System (BIORAD, Hercules, CA, USA). Relevant fractions of the eluted proteins were combined in a $10 \mathrm{kDa}$ Amicon ultrafiltration tube (MilliporeSigma, MA, USA) and centrifuged at $4{ }^{\circ} \mathrm{C}$ and $4000 \mathrm{rpm}$ till the volume was down to approximately $2.5 \mathrm{~mL}$. The concentrated protein was desalted using a PD-10 column (GE, Healthcare, New York, NY, USA) and 2 mL, $100 \mathrm{mM}$ KPi buffer pH 7.0.

\subsection{Protein Analysis}

The protein concentration was determined using the Bradford assay with BSA as a standard. SDS-PAGE was performed using 12\% Bis-Tris precast gels running in 1x XT MES buffer, at $200 \mathrm{~V}$ for $40 \mathrm{~min}$. The gel was stained using Simply Blue Safe Stain solution (Novex).

\subsubsection{Activity Assay}

DERA activity was measured using a coupled enzyme assay that has been reported previously [21]. DERA catalyzes the decomposition of 2-deoxy-D-ribose 5-phosphate to glyceraldehyde-3-phosphate and acetaldehyde. GAP is reduced to glycerol 3-phosphate by the enzymes $\alpha$-glycerophosphate dehydrogenase (GDH) and triosephosphate isomerase (TPI). This reaction is monitored via the simultaneous oxidation of nicotinamide adenine dinucleotide (NADH). The activity of $P a$ DERA is determined by analyzing the consumption of NADH. One unit of aldolase was defined as the amount of enzyme able to catalyze the cleavage of $1.0 \mu \mathrm{mol}$ of substrate (DR5P) per minute. 
In a $2.5 \mathrm{~mL}$ PMMA cuvette, $0.2 \mathrm{mM}$ NADH, $0.4 \mathrm{mM}$ DR5P, 3U GDH, 11U TPI and $10 \mu \mathrm{L}$ of protein sample were mixed. The volume was made up to $1 \mathrm{~mL}$ using $100 \mathrm{mM}$ triethanolamine buffer (TEA) at $\mathrm{pH} 7.0$ and the absorbance of NADH consumption was monitored for $1 \mathrm{~min}$ at $25^{\circ} \mathrm{C}$ and $750 \mathrm{rpm}$. The temperature and stirring speed were controlled using the TC1 Temperature Controller (Quantum Northwest, Liberty Lake, Washington, USA) (Company, City, State Abbr. (if has), Country) and absorbance measurements were detected at $340 \mathrm{~nm}$ using the Cary $60 \mathrm{UV}$-Vis Spectrophotometer (Agilent Technologies, California, USA) (Company, City, State Abbr. (if has), Country).

\subsubsection{Determination of $\mathrm{pH}$ and Temperature Optima and Kinetic Parameters}

The optimum $\mathrm{pH}$ was determined using the standard activity assay of the purified enzyme $(1 \mathrm{mg} / \mathrm{mL})$ at different buffers $(100 \mathrm{mM})$ in the $\mathrm{pH}$ range from 4 to 11: Sodium citrate ( $\mathrm{pH} 4.2,5$ and 6.2), potassium phosphate ( $\mathrm{pH} 6.2,7.0$ and 8.2), triethanolamine ( $\mathrm{pH} 7.0,8$ and 8.3) and glycine- $\mathrm{NaOH}$ $(\mathrm{pH} 8.6,9.0,10.0$ and 10.6). For the determination of the temperature optima, purified enzyme $(1 \mathrm{mg} / \mathrm{mL})$ was incubated at various temperatures between $20^{\circ} \mathrm{C}$ and $80^{\circ} \mathrm{C}$ in $10{ }^{\circ} \mathrm{C}$ increments. Samples were taken at two different time points 10 and $60 \mathrm{~min}$ (see Figure 1) and residual activity was measured using the coupled enzyme assay described above. Non-incubated enzyme was taken as a control. To obtain the Michaelis-Menten kinetic parameters, the activity assay was performed as described above for various substrate DR5P concentrations. The standard reaction mixture contained a particular concentration of DR5P, $0.2 \mathrm{mM} \mathrm{NADH}, 3 \mathrm{U}$ GDH, $11 \mathrm{U}$ TPI and $10 \mu \mathrm{L}$ DERA. The volume was made up to $1 \mathrm{~mL}$ with TEA buffer. All measurements were performed in duplicate. Data fitting was done using Prism (GraphPad) (GraphPad Software Inc., California, USA).

\subsubsection{Acetaldehyde Resistance of DERA}

The purified enzyme $(1 \mathrm{mg} / \mathrm{mL})$ was incubated at $25^{\circ} \mathrm{C}$ in $100 \mathrm{mM}, 200 \mathrm{mM}$ or $300 \mathrm{mM}$ of $99.5 \%$ pure acetaldehyde obtained from Sigma-Aldrich chemicals. Samples were drawn at 20, 45, 60 and $90 \mathrm{~min}$ and residual activity was measured using the coupled enzyme assay as described above. Enzyme that was incubated at $25^{\circ} \mathrm{C}$ in the absence of acetaldehyde was taken as a control $(0 \mathrm{~min})$.

\subsubsection{Sequential Aldol Reaction}

The reaction was carried out using $3 \mathrm{mg} / \mathrm{mL}$ PaDERA expressing whole cells, $100 \mathrm{mM}$ TEA buffer $\mathrm{pH} 7.0$ acetaldehyde $100 \mathrm{mM}$ in a total volume of $10 \mathrm{~mL}$. The reaction was stirred at $30{ }^{\circ} \mathrm{C}$ for $48 \mathrm{~h}$. The reaction was extracted with ethyl acetate and dried over anhydrous $\mathrm{Na}_{2} \mathrm{SO}_{4}$. The solvent was evaporated. The crude lactol was purified by silica column chromatography (BÜCHI LABORTECHNIK AG, Flawil, Switzerland) with EtOAc: Pet. Ether (30:70) as an eluent yielding pure 2,4,6-trideoxy-D-erythrohexapyranoside and subjected to GC (GC-2014, Shimadzu, Kyoto, Japan), ${ }^{1} \mathrm{H}$ NMR and ${ }^{13} \mathrm{C}$ NMR (Figure S7) (Agilent Technologies, California, USA) (Company, City, State Abbr. (if has), Country); ${ }^{1} \mathrm{H}$ NMR (400 MHz, Chloroform-d) $\delta 5.31(\mathrm{~d}, \mathrm{~J}=5.0 \mathrm{~Hz}, 1 \mathrm{H}, \alpha), 5.15(\mathrm{br}, 1 \mathrm{H}, \beta)$, $4.41(\mathrm{dtd}, \mathrm{J}=12.4,6.2,2.3 \mathrm{~Hz}, 1 \mathrm{H}, \alpha), 4.31(\mathrm{~s}, 1 \mathrm{H}, \beta), 4.21(\mathrm{dt}, \mathrm{J}=6.7,3.5 \mathrm{~Hz}, 1 \mathrm{H}, \alpha), 4.05(\mathrm{q}, \mathrm{J}=6.2$, $5.7 \mathrm{~Hz}, 1 \mathrm{H}, \beta), 3.11(\mathrm{br}, 1 \mathrm{H}, \beta), 3.01-2.97(\mathrm{~m}, 1 \mathrm{H}, \alpha), 2.03-1.91(\mathrm{~m}, 2 \mathrm{H}, \beta), 1.80(\mathrm{ddp}, \mathrm{J}=11.7,6.0$, $3.0 \mathrm{~Hz}, 2 \mathrm{H}, \alpha), 1.66-1.58(\mathrm{~m}, 2 \mathrm{H}, \beta), 1.52$ (dddd, J = 14.1, 11.7, 5.9, 2.4 Hz, 2H, $\alpha), 1.24(\mathrm{~s}, 1 \mathrm{H}, \beta)$, $1.20(\mathrm{t}, \mathrm{J}=6.2 \mathrm{~Hz}, 3 \mathrm{H}, \alpha) ;{ }^{13} \mathrm{C}$ NMR $(101 \mathrm{MHz}$, Chloroform-d) $\alpha$ anomer $\delta$ 93.0, 65.1, 58.9, 39.9, 34.9, 21.5. $\beta$ anomer $\delta 92.3,66.6,65.6,39.6,39.5,21.4$ in accordance with literature [17].

\section{Conclusions}

In summary, the new improved PaDERA C49M was successfully introduced as a biocatalyst for the sequential aldol reaction with high substrate loading. Both variants PaDERA and PaDERA C49M were purified and characterized. PaDERA has a basic $\mathrm{pH}$ optimum and a high acetaldehyde tolerance. Overall, this study shows that PaDERA is a promising new member that can be added to the DERA toolbox. 


\section{Patents}

There are no patents resulting from the work reported in this manuscript.

Supplementary Materials: The following are available online at http://www.mdpi.com/2073-4344/10/8/883/s1, Table S1: Primers used in this work. Table S2: Overview of enzyme properties and acetaldehyde resistance of DERA isolated from different organisms. Figure S1: Sequences alignment of PaDERA (WT) with EcDERA. Region represents sequence similarity around position C47 (in EcDERA) and C49 (in PaDERA). Figure S2: Comparison of translated amino acid sequences of $\mathrm{PaDERA} C$-his with extra amino acids and the C49M mutation. Figure S3: Michaelis-Menten curves of different DERA variants including EcDERA (a), PaDERA (b) and PaDERA with extra amino acids (c). Figure S4: The purification of PaDERA C49M. Figure S5: SDS-PAGE analysis of the purified PaDERA C49M. Figure S6: Screening of PaDERAC49M for aldol condensation of acetaldehyde GC. Figure S7: ${ }^{1} \mathrm{HNMR}$ and ${ }^{13} \mathrm{CNMR}$ analysis for aldol product.

Author Contributions: Conceptualization, Data curation, M.H., C.B., L.M.C., S.R.M., F.T., R.M. and E.A.; Formal analysis, P.-L.H.; Funding acquisition, U.H.; Investigation, M.H., C.B., L.M.C., S.R.M., F.T., R.M. and E.A.; Methodology, M.H., C.B., L.M.C. and E.A.; Supervision, U.H.; Writing—original draft, E.A.; Writing—review \& editing, M.H., C.B., L.M.C., S.R.M., F.T., R.M., A.I., E.L., P.-L.H., U.H. and E.A. All authors have read and agreed to the published version of the manuscript.

Funding: This study was funded by NWO-ERACoBiotech (grant 053.80.737).

Acknowledgments: We gratefully acknowledge generous financial support from NWO-ERA CoBiotech (grant 053.80.737). We thank Jörg Pietruszka (Jülich) for supplying the EcDERA expression plasmid. The authors gratefully acknowledge TU Delft for the scientific support.

Conflicts of Interest: The authors declare that they have no conflict of interest.

\section{References}

1. Salleron, L.; Magistrelli, G.; Mary, C.; Fischer, N.; Bairoch, A.; Lane, L. DERA is the human deoxy ribose phosphate aldolase and is involved in stress response. Biochim. Biophys. Acta Mol. Cell Res. 2014, 1843, 2913-2925. [CrossRef] [PubMed]

2. Racker, E. Enzymatic synthesis of deoxy pentose phosphate. Nature 1951, 167, 408-409. [CrossRef] [PubMed]

3. Liu, J.; Wong, C.-H. Aldolase-Catalyzed Asymmetric Synthesis of Novel Pyranose Synthons as a New Entry to Heterocycles and Epothilones. Angew. Chem. Int. Ed. 2002, 41, 1404-1407. [CrossRef]

4. Barbas, C.F.; Wang, Y.F.; Wong, C.H. Deoxyribose-5-phosphate aldolase as a synthetic catalyst. J. Am. Chem. Soc. 1990, 112, 2013-2014. [CrossRef]

5. Valino, A.L.; Iribarren, A.M.; Lewkowicz, E. New biocatalysts for one pot multistep enzymatic synthesis of pyrimidine nucleoside diphosphates from readily available reagents. J. Mol. Catal. B Enzym. 2015, 114, 58-64. [CrossRef]

6. Valino, A.L.; Palazzolo, M.A.; Iribarren, A.M.; Lewkowicz, E. Selection of a new whole cell biocatalyst for the synthesis of 2-deoxyribose-5-phosphate. Appl. Biochem. Biotechnol. 2012, 166, 300-308. [CrossRef] [PubMed]

7. Gijsen, H.J.M.; Wong, C.-H. Unprecedented Asymmetric Aldol Reactions with Three Aldehyde Substrates Catalyzed by 2-Deoxyribose-5-phosphate Aldolase. J. Am. Chem. Soc. 1994, 116, 8422-8423. [CrossRef]

8. Gijsen, H.J.M.; Wong, C.-H. Sequential one-pot aldol reactions catalyzed by 2-deoxyribose-5-phosphate aldolase and fructose-1,6-diphosphate aldolase. J. Am. Chem. Soc. 1995, 117, 2947-2948. [CrossRef]

9. Gijsen, H.J.M.; Wong, C.-H. Sequential three- and four-substrate aldol reactions catalyzed by aldolases. J. Am. Chem. Soc. 1995, 117, 7585-7591. [CrossRef]

10. Machajewski, D.T.; Wong, C.-H. The catalytic Asymmetric Aldol Reaction. Angew. Chem. Int. Ed. 2000, 39, 1352. [CrossRef]

11. Xuri, W.; Jinpeng, J.; Yijun, C. Correlation between Intracellular Cofactor Concentrations and Biocatalytic Efficiency: Coexpression of Diketoreductase and Glucose Dehydrogenase for the Preparation of Chiral Diol for Statin Drugs. ACS Catal. 2011, 1, 1661.

12. Haridas, M.; Abdelraheem, E.M.M.; Hanefeld, U. 2-Deoxy-D-ribose-5-phosphate aldolase (DERA): Applications and modifications. Appl. Microbiol. Biotechnol. 2018, 102, 9959-9971. [CrossRef] [PubMed]

13. Gijsen, H.J.M.; Qiao, L.; Fitz, W.; Wong, C.-H. Recent Advances in the Chemoenzymatic Synthesis of Carbohydrates and Carbohydrate Mimetics. Chem. Rev. 1996, 96, 443-473. [CrossRef] [PubMed]

14. Schürmann, M. An Aldolase for the synthesis of the statin side chain. In Industrial Enzymes Applications; Wiley-VCH: Weinheim, Germany, 2019; pp. 385-403. 
15. Huffman, M.A.; Fryszkowska, A.; Alvizo, O.; Borra-Garske, M.; Campos, K.R.; Canada, K.A.; Devine, P.A.; Duan, D.; Forstater, J.H.; Grosser, S.T.; et al. Design of an in vitro biocatalytic cascade for the manufacture of islatravir. Science 2019, 366, 1255-1259. [CrossRef] [PubMed]

16. Dick, M.; Hartmann, R.; Weiergräber, O.H.; Bisterfeld, C.; Classen, T.; Schwarten, M.; Neudecker, P.; Willbold, D.; Pietruszka, J. Mechanism-based inhibition of an aldolase at high concentrations of its natural substrate acetaldehyde: Structural insights and protective strategies. Chem. Sci. 2016, 7, 4492-4502. [CrossRef] [PubMed]

17. Abate, A.; Brenna, E.; Costantini, A.; Fuganti, C.; Gatti, F.G.; Malpezzi, L.; Serra, S. Enzymatic Approach to Enantiomerically Pure 5-Alken-2,4-diols and 4-Hydroxy-5-alken-2-ones: Application to the Synthesis of Chiral Synthons. J. Org. Chem. 2006, 71, 5228-5240. [CrossRef] [PubMed]

18. Sakuraba, H.; Yoneda, K.; Yoshihara, K.; Satoh, K.; Kawakami, R.; Uto, Y.; Tsuge, H.; Takahashi, K.; Hori, H.; Ohshima, T. Sequential aldol condensation catalyzed by hyperthermophilic 2-deoxy-d-ribose-5-phosphate aldolase. Appl. Environ. Microbiol. 2007, 73, 7427-7434. [CrossRef] [PubMed]

19. Kullartz, I.; Pietruszka, J. Cloning and characterisation of a new 2-deoxy-d-ribose-5-phosphate aldolase from Rhodococcus erythropolis. J. Biotechnol. 2012, 161, 174-180. [CrossRef] [PubMed]

20. Fei, H.; Xu, G.; Wu, J.-P.; Yang, L.-R. Improving the acetaldehyde tolerance of DERASEP by enhancing the rigidity of its protein structure. J. Mol. Catal. B Enzym. 2015, 116, 148-152. [CrossRef]

21. Nicholas, P.C. Determination of fructose-1,6-diphosphate aldolase activity with glyceraldehyde-3-phosphate dehydrogenase and diformazan formation. Biochem. Soc. Trans. 1988, 16, 753-754. [CrossRef]

(C) 2020 by the authors. Licensee MDPI, Basel, Switzerland. This article is an open access article distributed under the terms and conditions of the Creative Commons Attribution (CC BY) license (http://creativecommons.org/licenses/by/4.0/). 